\title{
Penyebab Tingginya Angka Anak Putus Sekolah Jenjang Sekolah Dasar (SD)
}

\author{
${ }^{*}$ Ayu Yeni Budi Lestari' ${ }^{1}$, Fariz Kurniawan², Rifal Bayu Ardi ${ }^{3}$ \\ ${ }^{123}$ Program studi S1 sistem informasi Fakultas Ilmu Komputer, Universitas Duta Bangsa
}

\section{A R T I C L E I N F O}

Article history:

1 Maret 2020 Received in revised form

30 Maret 2020

Accepted 11 April 2020

Available online 15

Mei 2020

\section{Kata Kunci:}

Putus Sekolah

Sekolah Dasar

Keywords:

Drop out,

Elementary School.

\begin{abstract}
A B S T R A K
Putus sekolah adalah fenomena masalah yang saat ini masih sering kita temui, masalah ini berlangsung selama beberapa waktu dan cukup sulit untuk menemukan solusi sebagai pemecahan dari fenomena masalah tersebut. Banyak faktor-faktor yang menjadi penyebab dari masalah ini seperti faktor internal yang merupakan faktor dari siswa sendiri,dan juga faktor eksternal yang berasal dari keluarga dan pengaruh lingkungannya. Saat ini masih banyak kita jumpai kasus anak putus sekolah khususnya pada bangku pendidikan Sekolah Dasar. Tujuan dari penelitian berikut adalah mengetahui faktor yang menjadi penyebab tingginya putus sekolah pada pelajar-pelajar Sekolah Dasar di wilayah Provinsi Jawa Tengah. Metode kualitatif ini dipilih untuk memberikan pemahaman dan visual secara mendalam mengenai penyebab dari tingginya fenomena. Dalam metode kualititatif, kelompok kami sebagai peneliti akan memposisikan diri langsung ditengah masyarakat, karena pada dasarnya permasalahan yang menjadi bahasan penelitian ini
\end{abstract} penting. Dalam menghimpun data, digunakan metode wawancara dari partisipan, dan studi pustaka dengan cara mempelajari data sekunder yang berupa dokumen, arsip, hasil riset hasil penelitian yang sudah dilakukan sebelumnya. Metode analisis data kualitatif akan dipakai karena data yang diperoleh adalah data yang berasal dari observasi dan wawancara. Hasil penelitian ditemukan bahwa faktor utama penyebab anak putus sekolah adalah kendala ekonomi dan minimnya kemampuan dari orangtua peserta didik. Sedangkan faktor lain yang menjadi penyebabnya seperti keinginan untuk bekerja, membantu otang tua, dan akses menuju kesekolah yang jauh

\begin{abstract}
A B S T R A C T
A student drop out from school is phenomenon that still often today, this phenomenon lasts for some time and it is quite difficult to find a solution to solve this problem. Many factors can cause this problem, such as internal factors which are factors of the students themselves and external factors that come from the family and the influence from the environment. At present there are still many cases of students dropped out from school, especially in elementary school education. The aim of this research was to determine the factors that cause high dropped out students of elementary school in Central Java province. This research used qualitative method. In a qualitative method, our group as researchers would take position directly in the middle of the community because basically the issues were very important. The results showed that the main factors of the students dropped out from school were economic constraints and the lack of parents' ability. While another factor was the desire to work, help parents, and school access.
\end{abstract}

\section{Pendahuluan}

Pendidikan adalah hal yang penting bagi kehidupan, pendidikan tidak hanya ditunjukkan agar seseorang menjadi pandai dan ahli dalam suatu hal tertentu. Pendidikan juga dipakai dalam proses pembentukan karakter peserta didik, pembelajaran dalam penerapan budi pekerti, akhlak dan pengembangan bakat perserta didik dan juga untuk mengembangkan keterampilan yang belum atau sudah dimiliki peserta didik. Menurut Moses (2012) menyatakan pendidikan adalah proses pengalihan pendidikan secara sistematis dari seseorang kepada orang lain sesui tujuan yang sudah diprogramkan. Dengan adanya pengelaihan pengetahuan ini diharapkan adanya perubahan sikap, kedewasaan, serta keterampilah. Menurut Dalle dalam Hafid, dkk. (2014) pendidikan adalah usaha sadar yang dilakukan oleh oleh orang dewasa melalui kegiatan bimbingan, pembelajaran, dan latihan, yang berlangsung di sekolah 
dan diluar sekolah dalam kurun waktu sepanjang hayat untuk mempersiapkan peserta didik agar dapat menyiapkan diri untuk menghadapi kehidaupannya dimasyarakat. Pendidikan berperan penting dalam kehidupan, pendidikan bukan hanya dilakukan dalam waktu yang terbatas akan tetapi pendidikan dilakukan dalam waktu yang panjang. Pernyataan ini sesuai dengan pendapat dari (Ariyani, 2018) yaitu pendidikan adalah baian penting bagi kebutuhan manusia, karena pendidikan bersifat sepanjang hayat. Pernyataan ini juga didukung oleh Tenisa, dkk (2013) yang menyatakan bahwa pendidikan adalah kebutuhan mutlak bagi manusia yang dijalankan sepanjang wayat. Pendidikan dan manusia tidak bisa dipisahkan, manusia tidak akan jadi apa-apa tanpa adanya proses pendidikan, manusia tidak bisa mengembangakan potensi yang dimiliki ataupun mencapai apa yang menjadi cita-cita manusia. Dengan adanya pendidikan yang dirancang secara sistemastis dan terprogram akan mampu mengembangkan potensi yang dimiliki oleh manusia itu sendiri. Hal ini sesaui dengan fungsi pendidikan yaitu Pendidikan bertujuan sebagai untuk mengembangkan dan membentuk watak manusia yang bermatabat, cedas, beriman dan bertaqwa kepada Tuhan Yang Maha Esa, berakhlak mulia, sehat, berilmu, cakap, kreatif, mandiri dan menjadi warga negara yang demokratis serta bertanggung jawab. (UU Sisdiknas, 2011: 3 dalam (Dewi, Zukhri, \& Dunia, 2014).

Pendidikan dikelompokkan menjadi tiga yaitu pendidikan forma, pendidikan Non formal dan pendidikan informal. Pendidikan formal adalah salah satu pendidikan yang di lakasankan oleh lembaga pendidikan. Pendidikan formal dibedakan sesai jenjangnya antara lain SD, SMP, dan SMA. Pendidikan sekolah dasar adalah salah satu pendidikan yang diterima oleh anak yang ber umur 7-12 tahun. Menurut (Nurlaila, dkk 2017) sekolah dasar adalah lembaga pendidikan yang menyelenggarakan program pendidikan bagi anak yang berusia 6-12 tahun. Sedangkan menurut Ihsan (2008) sekolah dasar adalah sebuah program pendidikan yang dilaksanakan dalam kurun waktu 6 tahun. Pendidikan dasar memberikan peranan penting bagi ketelanjutan proses pedidikan anak. Pendidikan sekolah dasar mempunyai tujuan meletakkan dasar kecerdasan, pengetahuan, kepribadian, akhlak mulia, serta keterampilan untuk hidup mandiri dan mengikuti pendidikan lebih lanjut. Dengan pentingnya sekolah dasar bagi anak makanya pemerintah terrus menggencarkan usaha untuk terlaksananya pendidikan sekolah dasar secara berkualitas dan bermutu. Proses pendidikan di jenjang sekolah dasar akan dijadikan sebagai bekal dalam jenjang pendidikan yang lebih tinggi di masa depan. Di dalam buku Pendidikan Untuk Pembangunan Nasional yang ditulis oleh (Muhammad Ali, 2009: 33) menyebutkan ada 2 keutamaan primary education, yaitu : 1) Pihak yang terkait yaitu pelajar akan dibekali kemampuan dasar seperti membaca, menulis, berhitung, dan berfikir kritis, kemampuan dalam penggunaan sains teknologi, kemampuan untuk berkomunikasi dengan sesama melalui pendidikan dasar ini. Dan 2). Pada Pendidikan jenjang dasar akan memberikan dasar sebagai bekal menuju pendidikan yang lebih tinggi di masa depan, pendidikan tingkat dasar akan berpengaruh dalam studi ke jenjang yang lebih tinggi dimasa mendatang.

Akan tetapi masalah muncul, dalam beberapa tahun ajaran ini, sering terdengar informasi ataupun berita tentang jumlah kasus putus sekolah yang terus bertambah, khususnya terjadi di jenjang pendidikan sekolah dasar (SD). Putus sekolah seolah menjadi problematika yang belum dapat diselesaikan. Putus sekolah tentu saja akan membawa dampak negatif jika tidak diselesaikan secara baik. Berdasarkan data temuan yang diperoleh dari KEMDIKBUD, jumlah pelajar mengalami putus sekolah khususnya di jenjang SD pada wilayah provinsi Jateng selalu mengalami peningkatan setiap tahun ajarannya. Peningkatan dari fenomena tersebut dapat dilihat pada data yang telah disajikan dalam bentuk tabel 01 berikut ini.

Tabel 01. Data anak putus sekolah jenjang SD

\begin{tabular}{lll}
\hline No & Tahun Ajaran & Jumlah Kasus \\
\hline 1 & $2016 / 2017$ & 2.205 \\
2 & $2017 / 2018$ & 2.238 \\
3 & $2018 / 2019$ & 3.800 \\
\hline
\end{tabular}

(sumber : statistik kemdikbud)

Berdasarkan tabel tersebut pada tahun ajaran 2016/2017 ada sejumlah 2.205 kasus anak putus sekolah, pada tahun ajaran 2017/2018 terdapat peningkatan sejumlah 33 kasus dari tahun ajaran sebelumnya, dan pada tahun ajaran 2018/2019 terdapat peningkatan sejumlah 1.562 kasus dari tahun ajaran 2017/2018. Dari data yang tersaji diatas, dapat disimpulkan jika putus sekolah masih menjadi masalah yang memerlukan penyelesaian agar tidak semakin meningkat setiap tahunnya.

Putus sekolah ada situasi dimana seoarang anak tidak lagi mengikuti proses pembelajaran tanpa menyelesaikan dengan mendapatkan Ijasah. Contohnya seoarang anak yang berhenti sekolah saat dia kelas 3 SD. Anak putus sekolah jenjang pendidikan dasar, adalah anak usia sekolah jenjang pendidikan dasar yang berhenti dari sekolah yang bersangkutan sebelum waktu yang telah ditentukan dan sebelum 
mendapatkan ijazah dari sekolahnya. Putus sekolah adalah predikat yang diberikan kepada peserta didik yang tidak mampu menyelesaikan suatu jenjang pendidikan, sehingga tidak dapat melanjutkan studinya kejenjang pendidikan berikutnya (Gunawan, 2010). Menurut Vebrianto (1995) putus sekolah adalah seatu kejaian dimana siswa meninggalkan pelajaran sekolah sebelum menamatkan pendidikannya. Anak yang awalnya menegikuti pendidikan akan tetapi tidak bisa menyelesaikan programnya (Sugitno, 1999). Sedangkan menurut Manan (2007) putus sekolah adalah Anak putus sekolah biasanya diartikan sebagai anak yang berhenti sekolah akibat beberapa faktor yang antara lain faktor ekonomi, faktor kelauraga dan faktor dari diri anak sendiri. Hal tersebut didukung dengan hasil peneleitain yang dilakukan oleh (Ariyani, 2018) yang menyatakan bahwa Pada tahun 2016 prosentase jumlah anak putus sekolah di DIY sebesar 0,21\% dengan jumlah usia 15 tahun sebesar 277 jiwa (Sumber: DIKPORA DIY). Angka putus sekolah di Yogyakarta disebabkan oleh beberapa hal. Pertama, masalah ekonomi. Pernyataan ini didukung dengan usia sekolah mengalami putus sekolah dikarenakan faktor ekonomi. Kedua, rendahnya kesadaran orangtua akan pentingnya pendidikan. Pernyataan ini didukung dengan masih adanya fenomena sosial dimana masih ditemuinya beberapa kelompok masyarakat yang berpikiran bahwa anak perempuan tidak perlu menempuh pendidikan sampai jenjang pendidikan tinggi.

Banyak faktor yang mempengeruhi tingkat putus sekolah, faktor-faktor tersebut antara lain faktor yang berasal dari dalam diri anak yang berupa faktor psikologis, ataupun faktor fisik. Faktor psikologis anak misalnya rendahnya minat belajar siswa atau depresi karena tidak menikuti proses pembelajaran sedangkan faktor fisik cacat akibat kecelakaan, ataupun sakit yang berkepanjangan daln lain sebagainya. Faktor yang tidak kalah penting adalah faktor yang berasal dari luar diri anak yaitu faktor ekonomi keluarga, faktor kondisi kelaurga (perceraian orang tua), dan faktor lainya. Menurut Menurut Mc Millen Kaufman dan Whitener dalam (Suryadi, 2014) faktor putus sekolah ada dua yaitu faktor internal dan faktor ekstrnal. Faktor internal adalah faktor yang berasal dari anak yang putus ekolah tersebut misalnya kemalasan anak, hobi bermain akan, rendahnya minat untuk belajar anak, Sedangkan faktor eksternal merupakan faktor yang berasal dari luar diri anak berasal dari orang tua yakni keadaan ekonomi keluarga, perhatian orang tua, hubungan orang tua yang kurang harmonis, latar belakang pendidikan orang tua, ataupun lingkungan yang kurang mendukung seperti jarak rumah dengan sekolah yang jauh.

Adapun faktor penyebab anak putus sekolah Menurut Sukmadinata (Suyanto, 2003) adalah. Faktor utama Anak Putus Sekolah adalah kesulitan ekonomi atau karena orang tua tidak mampu menyediakan biaya bagi sekolah anak-anaknya. Sehingga anak harus berhenti sekolah karena orang tuanya tidak mempunyai uang untuk biaya sekolah anaknya. Di samping itu orang tua juga tidak mau kalau anaknya harus berhenti sekolah. Orang tua hanya ingin agar anak-anaknya bisa menuntut ilmu dan agar anak bisa meraih cita-citanya. Selain itu, tidak jarang terjadi orang tua meminta anaknya berhenti sekolah karena mereka membutuhkan tenaga anaknya untuk membantu pekerjaan orang tua.Misalnya di daerah perkotaan, Anak Putus Sekolah di bawah umur, bekerja di pabrik- pabrik untuk membantu ekonomi orang tua. Adapun di daerah pedesaan, selain di sektor pertanian dan perkebunan, biasanya Anak Putus Sekolah bekerja di sektor industri kecil, sektor informal, dan perdagangan tradisional. Imron (2012:159) merumuskan beberapa faktor putus sekolah yaitu: a. Ketidakmampuan mengikuti pelajaran. Hal ini membuat peserta didik merasa berat untuk melanjutkan pendidikannya. Oleh karena itu mereka perlu mendapatkan perlakuan khusus yang berbeda dengan peserta didik kebanyakan. b. Tidak memiliki biaya untuk sekolah. Hal ini banyak terjadi pada daerah pedesaan, mereka merasa biaya pendidikan terlalu mahal sehingga mereka tidak mampu menyekolahkan anak mereka. c. Sakit parah. Peserta didik yang sakit menyebabkan mereka tidak masuk sekolah sampai batas waktu yang ditentukan. Karena ia sudah jau tertinggal dengan peserta didik yang lain maka kemudian ia lebih memilih tidak sekolah. d. Peserta didik yang terpaksa harus berkerja. Di negara berkembang banyak pekerja anak yang masih umur sekolah dan semakin lama ia tidak dapat sekolah lagi karena ia masih berkerja. e. Membantu orang tua. Dikarenakan mereka harus membantu orang tua, sering mereka tidak mengikuti lagi pelajaran sekolah sehingga mereka di drops out. Hal ini terjadi karena yang bersangkutan tidak dapat dididik lagi. Hal itu disebabkan karena kemampuan belajar yang rendah atau karena yang bersangkutan tidak mau lagi belajar. g. Peserta didik drop out karena keinginan sendiri. Peserta didik yang demikian memang tidak dapat dipaksa untuk sekolah termasuk orang tuanya. h. Kasus pidana. Pidana yang dialami peserta didik untuk beberapa tahun bisa menjadikan peserta didik drop out dari sekolah.

Beberapa penelitain sudah dilkukan untuk menganalisis penyebab tingginya putus sekolah pada anak, antara alin sebagai berikut: penelitian yang dilakukan oleh (Sabarudin, Iru, \& Syahrir, 2018) yang menyatakan faktor-faktor penyebab putus sekolah di Desa Wanseriwu disebabkan oleh dua faktor yaitu faktor internal dan faktor eksternal, yang dimana faktor internal yakni 1. minat atau kemauan 2 . Kepercayaan pada diri sendiri, sedangkan faktor eksternal terdiri dari 1. Lingkungan keluarga, 2. 
Lingkungan sekolah, 3. Lingkungan masyarakat, 4. Faktor ekonomi, 5. Pemahaman orang tua terhadap pentingnya pendidikan. Menurut Kamsihyati, Sutomo, \& FS (2016) menyatakan bahwa anak-anak putus sekolah di Desa Jangrana Kecamatan Kesugihan Kabupaten Cilacap di karenakan oleh faktor lingkungan keluarga yaitu besarnya jumlah anak yang menjadi tanggungan orang tua, faktor lingkungan sekolah yaitu sering mengalami konflik dengan sesama teman di Sekolah, faktor lingkungan masyarakat karena masyarakat tempat ia tinggal mayoritas berpendidikan rendah, faktor ekonomi dalam bentuk kurangnya penyediaan perlengkapan dan sarana belajar oleh orang tua dan faktor minat karena anak memilih bekerja daripada melanjutkan sekolah. Faktor yang paling dominan penyebab anak putus sekolah di Desa Jangrana Kecamatan Kesugihan Kabupaten Cilacap adalah faktor minat. Pendapat dari Muamalah (2017) bahwa Penyebab anak putus sekolah ada 2 hal yaitu Faktor internal meliputi: diri anak dan sakit yang di derita, faktor ekternal meliputi: lingkungan, faktor ekonomi dan sosial. 2) Dampak anak putus sekolah juga menimbulkan dampak seperti memperbanyak pengangguran, menjadi beban bagi perangkat desa, dan kurangnya wawasan. 3). Upaya penanganan anak putus sekolah antara lain: dengan ikut kejar paket, mengadakan pengajian, dan memberikan ketrampilan bagi anak putus sekolah agar memiliki bekal untuk hidup nanti.

Berdasarkan jabaran masalah serta penelitian yang sudah dilakukan maka penelitian ini bertujuan untuk menganalisis penyebab tingkat putus sekolah jenjang sekolah dasar di Provinsi Jawa Tengah yang dilakukan melalui penelitian kualitatif dengan mengamati dan wawancara langsung ke masyarakat.

\section{Metode}

Penelitian ini adalah jenis penelitian kualitatif, metode kualitatif dipilih karena data yang diteliti merupakan hasil dari survey,wawancara dan observasi. Pentingnya penelitian ini dengan menggunakan penelitan kualitatif, agar hasil yang diberikan menjelaskan permasalahan anak putus sekolah lebih detail dan nyata. Dengan memasukkan metode deskriptif analitis bertujuan untuk memberikan informasi secara visual mengenai fenomena yang kami angkat sebagai bahan penelitian dan membandingkannya dengan data yang ada di lapangan. Kami akan menggunakan dua jenis data yang tersedia yaitu jenis primer dan sekunder. Jenis primer akan kami peroleh dengan metode penelitian langsung melalui partisipan/ responden yang ada di lapangan serta pihak-pihak terkait seperti anak yang mengalami putus sekolah. Sedangkan data penelitian sekunder yaitu mempelajari data yang sudah ada seperti hasil riset dan hasil dari penelitian yang sudah dilakukan sebelumnya (Rachmawati, 2007). Peneliti mengambil sampel dari beberapa penelitian yang dilakukan di beberapa wilayah kota dan kabupaten dari povinsi Jateng yaitu wilayah dari Kota Surakarta, Kabupaten Sukoharjo, Kabupaten Karanganyar, Kabupaten Wonogiri. Instrumen dalam penelitian berikut ini adalah peneliti sendiri, peneliti dapat langsung melihat, mengobservasi,dan merasakan tentang tentang apa yang terjadi pada subjek yang ditelitinya. Dengan memposisikan diri sebagai instrumen, dapat mempermudah peneliti dalam mengumpulkan, menganalisa, menyimpulkan data yang diperoleh. Dalam menghimpun data, kami akan menggunakan metode salah satunya adalah wawancara mendalam dari pihak-pihak yang terkait (Rahardjo, 2010). Juga dilakukan studi pustaka dengan pengumpulan dan mempelajari data sekunder yang berupa dokumen, arsip, hasil riset hasil penelitian yang sudah dilakukan sebelumnya.

Tahapan pengumpulan data dalam penelitian berikut melalui beberapa proses yaitu persiapan, pelaksanaan, dan penutup. 1) Pada tahap persiapan, peneliti mencari data resmi,t terkait meningkatnya jumlah fenomena masalahan putus sekolah di jenjang sekolah dasar. Dalam hal ini data dikeluarkan secara resmi oleh Kemdikbud agar terjamin validasinya. 2) Pada tahap pelaksanaan, peneliti mencari partisipan dari fenomena terkait yang nantinya diwawancarai dan diobservasi. Wawancara dilakukan secara tidak terstruktur karena langsung menanyakan garis besar permasalahan. Peneliti juga mengumpulkan hasil dari penelitian yang pernah dilakukan sebelumnya, untuk dijadikan sebegai referensi. 3) Pada tahap penutup, peneliti mencatat dan merekam informasi-informasi penting pendukung fenomena masalah yang disampaikan oleh partisipan. Peneliti mempelajari ulang informasi yang diberikan oleh partisipan untuk kemudian dianalisa dan disimpulkan.

Dalam validasi instrumen, peneliti melakukan pengujian kredibilitas yang meliputi perpanjangan pengamatan, peningkatan ketekunan, dan tringulasi. Perpanjangan pengamatan untuk mengecek kembali apakah data yang sebelumnya diperoleh merupakan data valid. Peningkatan ketekunan dengan melakukan observasi lebih cermat untuk mengambil kesimpulan dengan tepat. Tringulasi dilakukan dengan melakukan pengecekan data yang diperoleh dari peneliti lain. Dari hasil penelitian,teknik analisis dilakukan dengan penyajian data bentuk chart yang diperoleh dari penarikan kesimpulan. Teknik dari penelitian ini lebih menekan pada generalisasi dari hasil riset yang dilakukan. Metode analisis data deskriptif kualitatif dipakai sebagai pendukung serta akan memudahkan pengembangan teori yang sudah ditemukan sebelumnya melalui data mentah yang berasal dari penelitian responden/partisipan. Pada 
Metode kualitatif ini, pada tahap pertamanya Peneliti akan melakukan eksplorasi, menghimpun banyak data selengkap mungkin, sampai pada nantinya akan menghasilkan sebuah laporan dari penelitian yang dilakukan (Afiyanti, 2008).

\section{Hasil dan pembahasan}

Dari hasil penelitian yang telah di dapat mengenai faktor penyebab anak putus sekolah yang diperoleh dari hasil observasi serta hasil wawancara secara tidak terstruktur yang disajikan dalam bagan penelitian sebagai berikut:

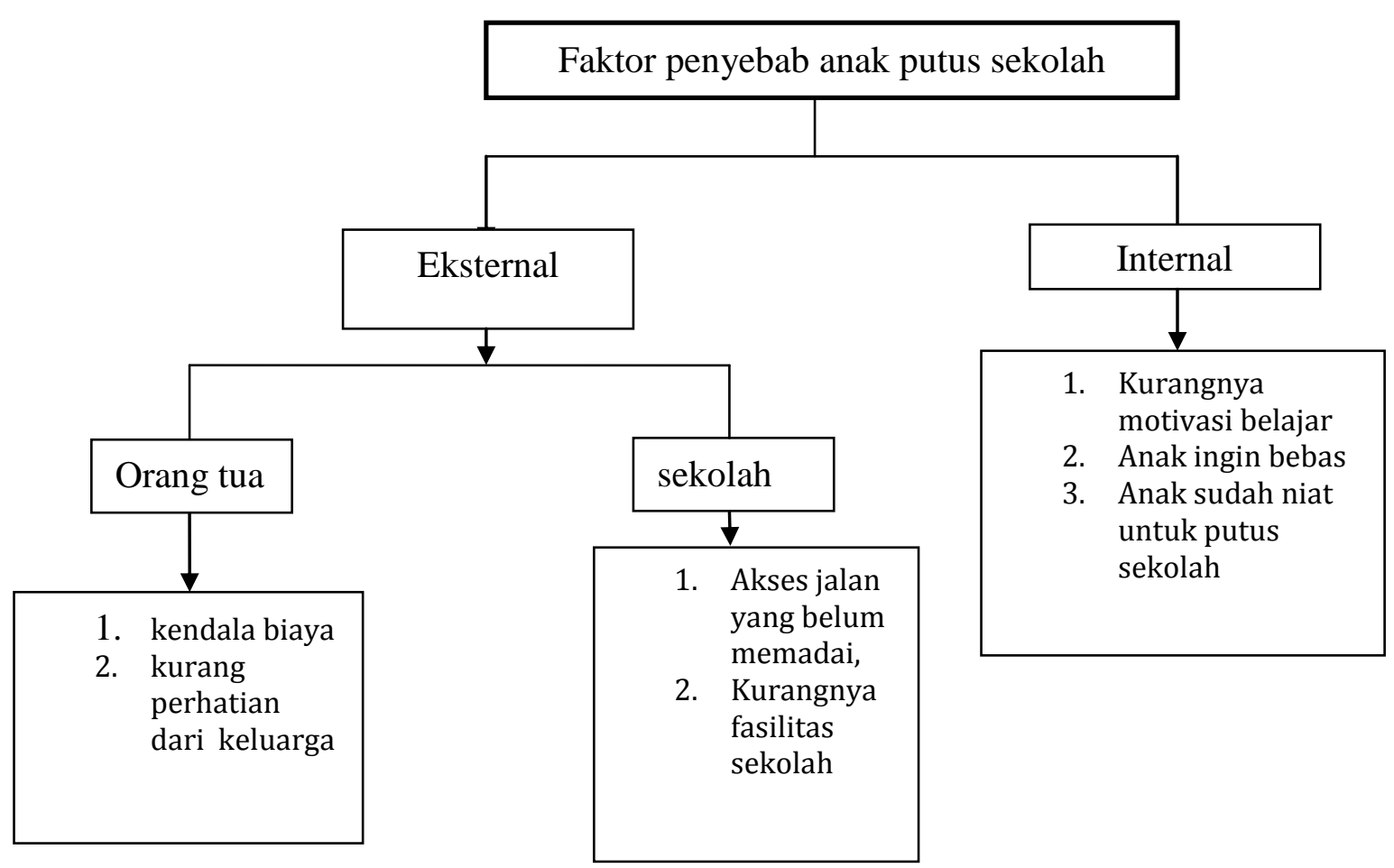

Gambar 01

Gambar faktor-faktor penyebab putus sekolah.

Dilihat dari hasil penelitian bahwa adanya beberapa faktor penyebab anak putus sekolah yaitu berasal dari faktor internal dan eksternal. Faktor internal adalah faktor yang berasal dari dalam diri seperti kurangnya minat anak, anak ingin bebas dan anak memang tidak suka sekolah dalam artian anak memang ingin berhenti sekolah. Sedangkan faktor dari luar diri anak, antara lain kondisi orang tua baik ekonomi, ataupun kondisi keharmonisan keluaraga. Sedangkan faktor luar dari sekolah misalnya jarak sekolah yang masih jauh dan sulit dijangkau oleh beberpa anak.

Sekolah dasar (SD) dimana proses pendidikan di sekolah dasar akan dijadikan sebagai bekal dalam menempuh jenjang pendidikan yang lebih tinggi di masa depan.Pendidikan adalah segala situasi hayati yang akan menghipnotis dan akan memberikan pengaruh kepada proses perkembangan dari individu. Sekolah dasar menjadi lembaga pendidikan resmi taraf awal/pertama. Segala hal yang diajarkan terhadap anak \& remaja yang menjadi peserta didik pada tingkat sekolah dasar ini agar siswa mempunyai kompetensi yang baik dan pencerahan penuh terhadap relasi serta tanggung jawab sosial mereka pada masyarakat. Sekolah Dasar di Indonesia sendiri memiliki 6 jenjang kelas, yaitu mulai dari kelas I sampai kelas VI. Pada jenjang-jenjang pendidikan berikut, anak mendapatkan mendapatkan materi-materi pembelajaran yang sesuai dengan umur dan kapasitasnya oleh guru pembimbing mereka. Saat ini, kita hidup dizaman serba berteknologi dimana teknologi juga dibutuhkan dalam mendukung kemajuan pendiidkan. Kebutuhan untuk mengimbangi masyarakat dan mempersiapkan siswa untuk peran mereka dalam masyarakat hanyalah adalah alasan untuk menggunakan teknologi dalam pendidikan. Pendidik dan peneliti menunjukkan potensi teknologi untuk meningkatkan motivasi dan keterlibatan peserta didik, memenuhi gaya belajar yang berbeda dan meningkatkan hasil belajar (Eady \& Lockyer, 2013). (Nurlaila, 
dkk 2017) menyatakan bahwa sekolah dasar adalah lembaga pendidikan yang menyelenggarakan program pendidikan bagi anak yang berusia 6-12 tahun. Sedangkan menurut Ihsan (2008) sekolah dasar adalah sebuah program pendidikan yang dilaksanakan dalam kurun waktu 6 tahun. Pendidikan dasar memberikan peranan penting bagi ketelanjutan proses pedidikan anak. Pendidikan sekolah dasar mempunyai tujuan meletakkan dasar kecerdasan, pengetahuan, kepribadian, akhlak mulia, serta keterampilan untuk hidup mandiri dan mengikuti pendidikan lebih lanjut. dengan pentingnya sekolah dasar bagi anak makanya pemerintah terrus menggencarkan usaha untuk terlaksananya pendidikan sekolah dasar secara berkualitas dan bermutu. Proses pendidikan di jenjang sekolah dasar akan dijadikan sebagai bekal dalam jenjang pendidikan yang lebih tinggi di masa depan. Di dalam buku Pendidikan Untuk Pembangunan Nasional yang ditulis oleh (Muhammad Ali, 2009: 33) menyebutkan ada 2 keutamaan primary education, yaitu : 1) Pihak yang terkait yaitu pelajar akan dibekali kemampuan dasar seperti membaca, menulis, berhitung, dan berfikir kritis, kemampuan dalam penggunaan sains teknologi, kemampuan untuk berkomunikasi dengan sesama melalui pendidikan dasar ini. dan 2). Pada Pendidikan jenjang dasar akan memberikan dasar sebagai bekal menuju pendidikan yang lebih tinggi di masa depan, pendidikan tingkat dasar akan berpengaruh dalam studi ke jenjang yang lebih tinggi dimasa mendatang seperti (SLTP) dan (SLTA).

Disini peran dan keahlian guru juga penting karena guru akan memandu dan memberikan pengalaman dalam setiap pembelajaran yang diberikan tidak hanya berdasarkan pada kemajuan teknologi saja (Cuban, 2003). Tingginya angka anak putus sekolah, khususnya yang berada ditingkat SD di wilayah provinsi Jawa Tengah perlu memerlukan perhatian yang lebih mendalam, karena pada jenjang Sekolah Dasar menjadi lembaga pendidikan resmi taraf awal/pertama yang ditempuh oleh anak \& remaja.Tingkat sekolah dasar ini dibentuk agar siswa mempunyai kompetensi yang baik dan pencerahan penuh terhadap relasi serta tanggung jawab sosial mereka pada masyarakat.

Putus sekolah ada situasi dimana seoarang anak tidak lagi mengikuti proses pembelajaran tanpa menyelesaikan dengan mendapatkan Ijasah. Contohnya seoarang anak yang berhenti sekolah saat dia kelas 3 SD. Anak putus sekolah jenjang pendidikan dasar, adalah anak usia sekolah jenjang pendidikan dasar yang berhenti dari sekolah yang bersangkutan sebelum waktu yang telah ditentukan dan sebelum mendapatkan ijazah dari sekolahnya. Putus sekolah adalah predikat yang diberikan kepada peserta didik yang tidak mampu menyelesaikan suatu jenjang pendidikan, sehingga tidak dapat melanjutkan studinya kejenjang pendidikan berikutnya (Gunawan, 2010). Menurut Vebrianto (1995) putus sekolah adalah seatu kejaian dimana siswa meninggalkan pelajaran sekolah sebelum menamatkan pendidikannya. Anak yang awalnya menegikuti pendidikan akan tetapi tidak bisa menyelesaikan programnya (Sugitno, 1999). Sedangkan menurut Manan (2007) putus sekolah adalah Anak putus sekolah biasanya diartikan sebagai anak yang berhenti sekolah akibat beberapa faktor yang antara lain faktor ekonomi, faktor kelauraga dan faktor dari diri anak sendiri. Hal tersebut didukung dengan hasil peneleitain yang dilakukan oleh (Ariyani, 2018) yang menyatakan bahwa Pada tahun 2016 prosentase jumlah anak putus sekolah di DIY sebesar 0,21\% dengan jumlah usia 15 tahun sebesar 277 jiwa (Sumber: DIKPORA DIY). Angka putus sekolah di Yogyakarta disebabkan oleh beberapa hal. Pertama, masalah ekonomi. Pernyataan ini didukung dengan usia sekolah mengalami putus sekolah dikarenakan faktor ekonomi. Kedua, rendahnya kesadaran orangtua akan pentingnya pendidikan. Pernyataan ini didukung dengan masih adanya fenomena sosial dimana masih ditemuinya beberapa kelompok masyarakat yang berpikiran bahwa anak perempuan tidak perlu menempuh pendidikan sampai jenjang pendidikan tinggi. Banyak faktor yang mempengaruhi peristiwa tersebut, diantaranya adalah faktor biaya, orangtua dan motivasi dari peserta didik.

Adapun faktor penyebab anak putus sekolah Menurut Sukmadinata (Suyanto, 2003) adalah. Faktor utama Anak Putus Sekolah adalah kesulitan ekonomi atau karena orang tua tidak mampu menyediakan biaya bagi sekolah anak-anaknya. Sehingga anak harus berhenti sekolah karena orang tuanya tidak mempunyai uang untuk biaya sekolah anaknya. Di samping itu orang tua juga tidak mau kalau anaknya harus berhenti sekolah. Orang tua hanya ingin agar anak-anaknya bisa menuntut ilmu dan agar anak bisa meraih cita-citanya. Selain itu, tidak jarang terjadi orang tua meminta anaknya berhenti sekolah karena mereka membutuhkan tenaga anaknya untuk membantu pekerjaan orang tua.Misalnya di daerah perkotaan, Anak Putus Sekolah di bawah usia, bekerja di pabrik- pabrik untuk membantu ekonomi orang tua. Adapun di daerah pedesaan, selain di sektor pertanian dan perkebunan, biasanya Anak Putus Sekolah bekerja di sektor industri kecil, sektor informal, dan perdagangan tradisional. Imron (2012:159) merumuskan beberapa faktor putus sekolah yaitu: a. Ketidakmampuan mengikuti pelajaran. Hal ini membuat peserta didik merasa berat untuk melanjutkan pendidikannya. Oleh karena itu mereka perlu mendapatkan perlakuan khusus yang berbeda dengan peserta didik kebanyakan. b. Tidak memiliki biaya untuk sekolah. Hal ini banyak terjadi pada daerah pedesaan, mereka merasa biaya pendidikan terlalu mahal sehingga mereka tidak mampu menyekolahkan anak mereka. c. Sakit parah. Peserta didik yang sakit menyebabkan mereka tidak masuk sekolah sampai batas waktu yang ditentukan. Karena ia sudah 
jau tertinggal dengan peserta didik yang lain maka kemudian ia lebih memilih tidak sekolah. d. Peserta didik yang terpaksa harus berkerja. Di negara berkembang banyak pekerja anak yang masih usia sekolah dan semakin lama ia tidak dapat sekolah lagi karena ia masih berkerja. e. Membantu orang tua. Dikarenakan mereka harus membantu orang tua, sering mereka tidak mengikuti lagi pelajaran sekolah sehingga mereka di drops out. f. drop out oleh sekolah. Hal ini terjadi karena yang bersangkutan tidak dapat dididik lagi. Hal itu disebabkan karena kemampuan belajar yang rendah atau karena yang bersangkutan tidak mau lagi belajar. g. Peserta didik drop out karena keinginan sendiri. Peserta didik yang demikian memang tidak dapat dipaksa untuk sekolah termasuk orang tuanya. h. Kasus pidana. Pidana yang dialami peserta didik untuk beberapa tahun bisa menjadikan peserta didik drop out dari sekolah. Berdasarkan hasil penelitian yang dilakukan ada beberapa faktor yang ditemukan antara lain:

Pertama, kurangnya motivasi belajar. Motivasi bersal dari bahsa Latin yaitu movore yang artinya mengerakkan. Motivasi adalah suatu proses mendorong daan mempertahankan aktivitas agar tercapainya sebuh tujuan (Schunk, et al., 2012). Motivasi adalaha perubahan energy dalam diri seseorang yang ditandai dengan timbulnya perasaan dan reaksi agar tercapainya sebuah tujuan (Mc Donald dalam (Hamalik, 2003). Motivasi adalah serangkaian usaha untuk menyiapkan kondisi tertentu, sehingga seseorang mau dan ingin melakukan sesuatu. Sedangkan menurut Biehler dan Snowman dalam (Suyono, dkk., 2015) menyatakan bahwa motivasi adalah daya yang membangunkan, memilih, mengarahkan suatu prilaku. Motivasi sebagai proses yang dapat membangkitkan dan memabawa prilaku, memberikan arah prilaku dan tujuan prilaku, memungkinkan prilaku untuk melanjutkan dan memeilih prilaku tertentu. Menurut Wlodkowski 1991 dalam (Green \& Kelso, 2006). Motivasi dapat dibedakan menjadi dua yaitu motivasi intrinsic dan ekstrinsik. Motivasi intrinsic yaitu perasaan senang yang berasal dari dalam diri anak. Menurut Ryan dan Deci (2000) dalam (Erlisnawati, 2015) menyatakan bahwa motivasi intrinsic adalah sebagai dampak dari sebauh kegitan yang melekat pada seseorang yang berupa kepuasan, rasa senang yang mampu mendorong seseorang melakukan sesuatu. Motivasi intrinsic bagi anak adalah sebuah hasil pendidikan, anak mampu mengontrol, lebih percaya serta meraka menjadi lebih aktif sehingga tujuan dari sebuah program pendidikan itu dapat dihujudkan. Sedangkan motivasi eksternal Motivasi Ekstrinsik Motivasi ekstrinsik berfokus pada faktor-faktor eksternal untuk individu dan tugas, seperti imbalan, pujian, hak istimewa, atau perhatian (Palmer, 2005). Motivasi ekstrinsik adalah hal-hal di luar diri individu yang mendorong individu untuk melakukan sesuatu. Dari jabaran tersebut dapat dikatakan bahwa motivasi dari anak sangat dibutuhkan dalam kelanjutan proses pembelajaran. karena dengan adanya motivasi dari anak akan menumbuhkan rasa ingin melakukan sebauh kegiatan dengan baik. Tentunya motivasi ini dipengaruhi oleh beberapa faktor antara faktor kesiapan dan faktor sosial.

Kedua, Anak yang tidak peduli. Rasa tidak peduli anak bisa disebabkan oleh banyak faktor. Tapi peran orang tua disini sangatlah besar. Bagaimana pola asuh anak sangat mempengaruhi kondisi anak. di keluargalah anak akan belajar segala hal pertama dengan keluaraga. Kelaurga yang mempunyai pola asuh yang baik akan menghasilkan anak yang baik pula. Hal ini didukung oleh pernyataan Adanya hubungan yang positif antara pola asuh orang tua dengan kepedulian sosial remaja dipertegas oleh Musaheri (2007) dalam (Aditia, Hamiyati, \& Rusilanti, 2016) mengemukakan bahwa pola asuh merupakan suatu kegiatan yang dilakukan secara terpadu dalam jangka waktu yang lama oleh orang tua kepada anaknya dengan tujuan untuk membimbing, membina dan melindungi anak. Pola asuh merupakan interaksi antara orang tua dengan anak, interaksi disini termasuk ekspresi sikap, nilai, perhatian dalam membimbing, mengurus, dan melatih perilaku anak. Maka dari itu orang tua perlu memberikan pola asuh yang baik bagi anak dan mengajarkan nilai- nilai sosial, karena bagaimana orang tua mendidik anak sangat penting agar anak mempunyai nilai sosial yang tinggi. Lingkungan keluarga sangat berperan penting bagi pembentukan karakter perkembangan pada anak, jika orangtuanya tidak memberikan rasa kepedulian kepada anak, maka anak juga seperti itu. Hal ini dinyatakan dengan tidak peduli dengan yang di minta oleh orangtuanya, anak selalu mengabaikan perintah dari orang tua.

Ketiga. Anak yang ingin bebas. Kebebasan merupakan potensi untuk membuat diri seseorang terhadap dunianya. Keinginan manusia untuk bebas merupakan keinginan yang sangat mendasar, anak sudah tidak mau lagi disuruh ini itu oleh orangtuanya dan anak mengurusi hidupnya dengan sesukanya saja, apa yang diinginkan oleh orangtuanya sudah bertentangan dengan apa yang diinginkan anak, hal ini karena anak ingin bebas dari tugas tugas sekolah. Menurut Hipocrates (Tri, 2016) seseorang yang memiliki tipe plegmatis merupakan pribadi yang selalu cinta damai dengan menjadi netral dalam segala keadaan dan kondisi konflik tanpa memihak kubu manapun.

Keempat Kendala biaya. Menurut Wahyu (dalam Putri, 2018) Tingkat pendapatan merupakan Satuan tingkatan yang berasal dari pemasukan keuntungan yang dihasilkan dari penjualan barang dan jasa dalam jangka waktu tertentu. Menurut Bambang (1990: 18) berpendapat bahwa: "pendapatan berupa 
uang yaitu pendapatan berupa gaji dan gaji yang diperoleh dari hasil kerja pokok, kerja lembur, kerja sampingan dan kerja kadang - kadang. Usaha sendiri meliputi komisi dan penjualan dari kerajinan rumah tangga. dari hasil investasi yakni pendapatan yang diperoleh dari kerja sosial, pendapatan berupa beras, pengobatan, transportasi, perumahan, rekreasi, barang yang diproduksi dan konsumsi. Dari pendapat diatas, dapat diketahui sintesa tingkat pendapatan orang tua anak putus sekolah jenjang pendidikan dasar dalam penelitian ini adalah penghasilan yang diperoleh orang tua anak putus sekolah per bulan dari pekerjaannya dalam bentuk uang dan dipergunakan untuk memenuhi kebutuhan hidup keluarganya.

Kelima, Kurang perhatian dari keluarga. Anak juga diasuh secara permisif maka dari itu Anak memiliki sikap yang egois, kemandirian yang rendah, serta kurang bertanggungnya jawab dengan tugastugas yang Anak miliki. Orangtua subyek tidak pernah memberikan perhatian kepada Anak sehingga Anak mengatur hidupnya dengan se sukanya. Menurut Baumrind (dalam Husnatul, 2019) pola asuh permisif dimana pada pola asuh ini orangtua sangat terlibat dalam kehidupan anak-anak mereka, namun menetapkan sedikit batas atau kendali terhadap anak mereka. Orangtua cenderung membiarkan anakanak mereka melakukan apa saja, sehingga anak tidak dapat mengendalikan perilakunya serta tidak mampu untuk menaruh hormat pada orang lain.

Beberapa penelitian mendukung hasil temuan ini adalah (Liani \& Marpaung, 2019) menyatakan bahwa bahwa adanya beberapa faktor yang menyebabkan anak putus sekolah, yaitu 1) Penyebab kurang motivasi belajar 2) Anak ingin bebas 3) Anak tidak peduli 4) Penyebab orangtua disebabkan karena (a) Pola asuh orangtua yang otoriter (b) Pola asuh orangtua yang permisif (c) Orangtua sibuk dengan pekerjaannya. 5) Penyebab sekolah disebabkan karena (a) Bullying verbal (b) Tidak nyaman dengan suasana kelas. 6) Penyebab pengaruh teman sebaya. Penelitian yang dilakukan oleh (Sabarudin et al., 2018) yang menyatakan faktor-faktor penyebab putus sekolah di Desa Wanseriwu disebabkan oleh dua faktor yaitu faktor internal dan faktor eksternal, yang dimana faktor internal yakni 1. Minat atau kemauan 2. Kepercayaan pada diri sendiri, sedangkan faktor eksternal terdiri dari 1. Lingkungan keluarga, 2 . Lingkungan sekolah, 3. Lingkungan masyarakat,4. Faktor ekonomi, 5. Pemahaman orang tua terhadap pentingnya pendidikan. Menurut (Kamsihyati et al., 2016) menyatakan bahwa anak-anak putus sekolah di Desa Jangrana Kecamatan Kesugihan Kabupaten Cilacap di karenakan oleh faktor lingkungan keluarga yaitu besarnya jumlah anak yang menjadi tanggungan orang tua, faktor lingkungan sekolah yaitu sering mengalami konflik dengan sesama teman di Sekolah, faktor lingkungan masyarakat karena masyarakat tempat ia tinggal mayoritas berpendidikan rendah, faktor ekonomi dalam bentuk kurangnya penyediaan perlengkapan dan sarana belajar oleh orang tua dan faktor minat karena anak memilih bekerja daripada melanjutkan sekolah. Faktor yang paling dominan penyebab anak putus sekolah di Desa Jangrana Kecamatan Kesugihan Kabupaten Cilacap adalah faktor minat. Pendapat dari (Muamalah, 2017) bahwa Penyebab anak putus sekolah ada 2 hal yaitu Faktor internal meliputi: diri anak dan sakit yang di derita, faktor ekternal meliputi: lingkungan, faktor ekonomi dan sosial. 2) Dampak anak putus sekolah juga menimbulkan dampak seperti memperbanyak pengangguran, menjadi beban bagi perangkat desa, dan kurangnya wawasan. 3). Upaya penanganan anak putus sekolah antara lain: dengan ikut kejar paket, mengadakan pengajian, dan memberikan ketrampilan bagi anak putus sekolah agar memiliki bekal untuk hidup nanti.

Berdasarkan hasil analisa tersebut, terdapat beberapa faktor utama penyebab anak putus sekolah di karesidenan surakarta, yang terbagi menjadi faktor eksternal dan internal. Pada faktor eksternal yang menjadi penyebabnya adalah kendala ekonomi dan minimnya kemampuan dari orangtua peserta didik. Faktor kendala biaya menjadi faktor utama dalam fenomena ini, biaya dalam hal ini berkaitan dengan kebutuhan dalam sekolah seperti buku pelajaran, seragam dan atribut, pembayaran uang pembangunan dan biaya SPP bulanan yang masih sering diterapkan disekolah. Kedua, faktor minimnya kemampuan orang tua, orang tua yang memiliki pengalaman dan pemahaman terhadap pendidikan pasti akan selalu mendukung anak didalam belajar terutama dijenjang pendidikan dasar karena hal tersebut penting untuk masa depan mereka, jika anak melewatkan pendidikan dasar maka anak tidak akan bisa menempuh jenjang yang lebih tinggi dan belajar lebih banyak mengenai berbagai hal yang tidak bisa didapat melalui sistem pembelajaran non-formal. Faktor eksternal lainnya, adalah faktor yang berasal dari lingkungan sekolah yaitu jarak akses menuju sekolah dan kurangnya fasilitas, dibeberapa wilayah masih ditemui lokasi sekolah-sekolah yang kurang strategis dan jauh dari pemukiman, jarak akses menuju sekolah yang jauh dan tidak mudahnya akses transportasi akan menjadi salah satu faktor mengurangi semangat belajar dari peserta didik. Fasilitas dalam mendukung kegiatan belajar juga perlu diperhatikan karena dengan fasilitas yang baik, Selain faktor eksternal, juga terdapat faktor internal yang berasal dari diri siswa. Faktor internal tersebut adalah kurangnya motivasi siswa dalam belajar, keinginan anak untuk bebas dan tidak terikat oleh suatu lembaga, serta adanya keinginan anak untuk putus sekolah sejak awal agar bisa membantu orang tua dalam bekerja dan merantau. Pemerintah dalam hal ini sudah berupaya membuat program dan rencana kerja yang berkaitan dengan pendidikan agar semua anak mengenyam pendidikan 
dasar secara menyeluruh sehingga tingginya angka anak putus sekolah bisa ditekan setiap tahunnya. Jika angka putus sekolah setiap tahunnya tetap bertambah dan meningkat, maka akan menimbulkan dampak negatif, diantaranya adalah anak merasa rendah diri, stress, perkembangan emosi yang lambat, semakin tertutup pada potensi diri sendiri, menjadi pemalas, kurang pergaulan, tidak memiliki tujuan dan cita-cita, dan yang terpenting adalah kurangnya dari pengetahuan yang dimiliki. Berbagai pihak baik internal maupun eksternal perlu bekerjasama dalam mengentaskan putus sekolah, peran orangtua dalam membimbing anak juga sangat berpengaruh pada proses belajar dan masa depannya. Penerapan kebijakan-kebijakan baru yang berkaitan dengan wajib belajar dan peran pemerintah memberikan bantuan dalam rangka mensukseskan wajib belajar juga perlu untuk lebih dimaksimalkan.

\section{Simpulan dan saran}

Dari pembahasan dapat disimpulkan jika ada beberapa faktor utama penyebab anak mengalami putus sekolah di jenjang pendidikan dasar yang terbagi menjadi faktor eksternal dan faktor internal. Pada faktor eksternal, terbagi terbagi atas faktor yang berasal dari orangtua yang terkendala dalam membiayai pendidikan serta kurangnya kemampuan dalam memberikan dukungan motivasi kepada siswa. Faktor eksternal lainnya merupakan faktor yang berasal dari sekolah seperti minimnya akses dan kurangnya fasilitas sekolah. Sedangkan faktor internalnya merupakan hal yang berasal dari siswa sendiri yaitu kurangnya motivasi dalam belajar, keinginan untuk bebas, dan keinginan untuk tidak melanjutkan pendidikan.

\section{Daftar Rujukan}

Aditia, H. R., Hamiyati, H., \& Rusilanti, R. (2016). Hubungan Pola Asuh Orang Tua Dengan Kepedulian Sosial Remaja. JKKP (Jurnal Kesejahteraan Keluarga Dan Pendidikan), 3(2), 89-93. https://doi.org/10.21009/jkkp.032.08

Ali, Mohammad. 2009. Pendidikan untuk Pembangunan Nasional. Jakarta: Grasindo.

Ariyani, S. N. Q. (2018). Tren Angka Putus Sekolah Pendidikan Sekolah Menengah Pertama di Daerah Istimewa Yogyakarta. Jurnal Kebijakan Pendidikan, 7(4), 440-451. Retrieved from http://journal.student.uny.ac.id/ojs/index.php/sakp/article/view/13142

Badan Pusat Statistik Provinsi DIY. (2012). Daerah Istimewa Yogyakarta dalam Angka 2011. Yogyakarta: BPS Provinsi DIY. Diambil pada tanggal 02 November 2017, dari http://yogyakarta.bps.go.id.

Bambang Rianto. 1990. Dasar-dasar Pembelanjaan Perusahaan. Yogyakarta: Gadjah Mada University Press.

Cuban, L. (2003). "The great reappraisal of public education": The 1952 Charles P. Steinmetz memorial lecture. American Journal of Education. https://doi.org/10.1086/377671

Dewi, N. A. K., Zukhri, A., \& Dunia, I. K. (2014). Analisis Faktor-Faktor Penyebab Anak Putus Sekolah 2012 / 2013. Jurnal Juruan Pendidikan Ekonomi, 4(1), 1-12. Retrieved from https://ejournal.undiksha.ac.id/index.php/JJPE/article/view/1898

Eady, M. J., \& Lockyer, L. (2013). Tools for learning: technology and teaching strategies. Queensland University of Technology, Australia, (pp. 71).

Erlisnawati. (2015). Masalah Motivasi Belajar Siswa Sd Pada Ips. Jurnal Pendidikan Sekolah Dasar, 1(2).

Green, T. M., \& Kelso, C. M. (2006). Factors That Affect Motivation Among Adult Learners. Journal of College Teaching \& Learning (TLC), 3(4), 65-74. https://doi.org/10.19030/tlc.v3i4.1729

Gunawan, A. H. (2010). Sosiologi pendidikan: Suatu analisis sosiologi tentang pelbagai problem pendidikan. Jakarta: Rineka Cipta.H. Mudjia Rahardjo. (2010). Triangulasi dalam Penelitian Kualitatif. https://doi.org/10.1360/zd-2013-43-6-1064

Hafid, A., \& dkk. (2014). Konsep Dasar Ilmu Pendidikan. Bandung: Alfabeta.

Hamalik, O. (2003). Prosedur Belajar Mengajar. Jakarta: Bumi Aksara.Hasnatul,

Jannah. (2018). Bentuk Pola Asuh Orang Tua Dalam Menanamkan Perilaku Moral Pada Anak Usia Di Kecamatan Ampek Angkek. Pesona PAUD, Vol I, No 1. 
https://media.neliti.com/media/publications/157190-ID-none.pdflhsan,

Faud. (2008). Dasar-dasar Kependidikan Dasar. Bandung: Rineka Cipta Ress.

Imron, Ali. 2012. Manajemen Peserta Didik Berbasis Sekolah. Jakarta: Bumi Aksara.

Kamsihyati, T., Sutomo, \& FS, S. (2016). Kajian Faktor-Faktor Penyebab Anak Putus Sekolah di Desa Jangrana Kecamatan Kesugihan Kabupaten Cilacap. Geo Edukasi, 5(1), 16-21.

Liani, T., \& Marpaung, J. (2019). Faktor Penyebab Anak Putus Sekolah Causative Factors Of The Children's Drop Out Of School Tressia Liani 1 , Junierissa Marpaung 2. Pendidikan Agama Islam, 4(2), 26-38.

Manan, J. (2007). Dinamika Anak Putus Sekolah. Jakarta: Rajawali Pers.

Moses, M. (2012). Analisis Pengaruh Pendidikan, Pelatihan, Dan Pengalaman Kerja Terhadap Produktivitas Kerja Pegawai Dinas Pertambangan Dan Energi Provinsi Papua. Media Riset Bisnis \& Manajemen, 12(1), 18-36.

Muamalah, B. (2017). Studi Analisis Penanganan Anak Putus Sekolah Di Desa Ngepanrejo Kecamatan Bandongan Kabupaten Magelang Disusun. Universitas Muhammadiyah Surakarta. https://doi.org/10.1016/j.jpainsymman.2017.04.009

Nurlaila, S, \& dkk. (2017), Pengaruh Model Cooperative Learning Tipe Teams Games Tournaments (TGT) Terhadap Hasil Belajar Siswa Pada Mata Pelajaran IPS Di Kelas IV SDN Gugus X kota Bengkulu. Jurnal Riset Pendidikan Dasar, 1 (1) : 43 - 49

Palmer. (2005). A Motivational View of Constructivist- informed Teaching. International Journal of Science Education, 27(15).

Putri, Arini Eka. (2018). Analisis Faktor - Faktor Penyebab Anak Putus Sekolah Jenjang Pendidikan Dasar Di Kecamatan Ambarawa Kabupaten Jringsewu. Jurnal Unila. http://jurnal.fkip.unila.ac.id/index.php/jpg/article/download/16027/11573

Rachmawati, I. N. (2007). Pengumpulan Data Dalam Penelitian Kualitatif: Wawancara. Jurnal Keperawatan Indonesia, 11(1), 35-40. https://doi.org/10.7454/jki.v11i1.184

Sabarudin, Iru, L., \& Syahrir, A. (2018). Faktor-Faktor Penyebab Putus Sekolah (Studi Desa Wanseriwu Kecamatan Tiworo Tengah Kabupaten Muna Barat). Selami IPS, 3(47), 244-254. https://doi.org/10.1017/CB09781107415324.004

Schunk, D. ., \& et al. (2012). Motivasi dalam Pendidikan: Teori, Penelitian dan Aplikasi. In Edisi Ketiga. Terj: Ellys Tjo.

Sugitno, A. (1999). Pengantar Evaluasi Pendidikan. Jakarta: PT Raja Grafindo Persada.

Suryadi. (2014). Permasalahan Dan Alternatif Kebijakan Pendidikan Indonesia. Bandung: PT Remaja Rosdakarya.

Suyanto. (2003). Masalah Sosial Anak. Jakarta: Kencana Prenada Media Group.

Suyono, \& dkk. (2015). Implementasi Belajar dan Pembelajaran. Bandung: Remaja Rosdakarya.

Tri Ria Astuti. (2016). Deskripsi Kemampuan Pemecahan Masalah Matematis Siswa SMA Negeri 4 Purmokerto. Skripsi. Tidak Diterbitkan. FKIP Universitas Muhammadiyah Purwokerto.

Vebrianto. (1995). Pengaruh Keluarga Dalam Pendidikan Anak. Jakarta: Jaya Sakti.

Yati Afiyanti. (2008). Validitas dan Reliabilitas Instrumen Penelitian. Metode Penelitian Survai. 